\title{
Adaption and Memory: The Reckless Leader and The Effects of the First Family
}

\author{
Dionnie DeWitt
}

Regent University, School of Business Leadership, United States

\begin{tabular}{l} 
ARTICLE INFO \\
\hline Keywords: \\
Behavior \\
Empathy \\
Relationship \\
Self-Discipline \\
Silence
\end{tabular}

\begin{abstract}
There are harmful leaders, but too few instances of how harmful the leadership is within the church get explored and how it affects the first families. Several harmful leadership styles, such as an egotistical leader, an ignorant leader, and a reckless leader, studied in some capacity under leadership. There is an ideology put forward, and it is believed that leaders are not just appearing in business or corporate America, but leaders are leaders and are showing forth their leadership in everyday instances as a mother who teaches their child. The leader's leadership scope was explored by filtering it through adaption and memory, with memory being a significant part of this paper. The overall platform is looking at (reckless) leadership through the lens of religion (Christianity) with a philosophical undertone using personal reflections. The results for this research, under the assumption, of using the qualitative method and using two qualitative designs, helped with data collection. The narrative approach and the phenomenological approach show the leader's evolving behavior and the first family's behavior through personal observation with testimonies to expose the effects of their memory. Scriptures are used to expose or reveal the split leadership dynamic and how memory dictates leaders' response and behavior. Two individual stories were rendered, which more participants are needed to develop a consensus of adaption and memory in leadership and how it affects the first family. Understanding that some things are caught, and some things are taught, this study's outcome, by looking at leadership and the effects of the first family, concluding with the suggestion of furthering this research to explore a more in-depth understanding of reckless leadership in the scope of adaptation to memory.
\end{abstract}

\section{Introduction}

The role and style of leadership have been defined and viewed in many different ways because of the many school genres. For instance, there is the field of psychology, sociology, education, business, and health care, to name a few, and within all of the genres of thought have a different understanding of leading with leadership. The leadership dynamic has changed over time with more understanding of how to become one and how to evolve. As Bass (1990) put forward, that

\footnotetext{
*Corresponding author E-mail address: dionnie.dewitt@gmail.com 
leadership is an interaction between two or more members of a group that often involves a structuring or restructuring of the situation and the perceptions and expectations of members...leadership occurs when one group member modifies the motivation or competencies of others in the group. Any member of the group can exhibit some amount of leadership. (pp.19-31)

Simply put, leadership exists when there is a need for interaction with more than one person, which comes across as there is no need to lead when there is no interaction. Unfortunately, leadership's dynamic only gets reflected within the confines of business or work, but also, leadership can be found in everyday life as a mother teaches her child. The Bible conveys, "train up a child in the way he should go even when he is old, he will not depart from it" (Proverb 22:6, New American Standard Bible). For more clarity of the leadership of parents, "my son, observe the commandment of your father and do not forsake the teaching of your mother;" (Proverb 6:20, NASB). Understanding text training is a process in which memory and adaption take place to continue to follow the pattern that was taught.

There are harmful leaders, but too few instances of how harmful the leadership is within the church get explored and how it affects the first families. There are several harmful leadership styles, such as an egotistical leader, an ignorant leader, and a reckless leader, as put forward by (Burns 2017). The exploration of reckless leadership will be discovered from a Christian religious perspective by looking at the church's leadership dynamics and how reckless leadership affects the first families.

\subsection{First Family}

Before exploring the reckless leadership dynamic, the leader's leadership scope was explored by filtering it through, adaption, and memory and using memory as the significant part of this paper to explain reckless leadership's adaptive behavior. Firstly, taking a look at the definition of adaption, which is a change or the process of change and or the action or process of adapting (anonymous), likewise, memory is the mind that stores and remembers information. Giving that insight as a backdrop will help further the understanding of reckless leadership and how it affects the first family. Scripture will direct this paper for it is the guide for a Christian 2nd Timothy 3:16 states all scripture is breathed out by God and profitable for teaching, for reproof, for correction, and for training in righteousness that the man of God may be complete, equipped for every good work (2nd Timothy 3:16, NKJV). Scripture intends to reflect adaption and memory. Isaiah 26:3 You will keep him in perfect peace, whose mind is stayed on You because he trusts in You. (Isa. 26:3, NKJV). Jeremiah 17:10 I, the LORD, search the heart, I test the mind, even to give every man according to his ways, According to the fruit of his doings. (Jer. 17:10, NKJV).

Luke 10:27 So he answered and said, "You shall love the LORD your God with all your heart, with all your soul, with all your strength, and with all your mind,' and your neighbor as yourself.'" (Lk. 10:27 NKJ). Romans 12:16 Be of the same mind toward one another. Do not set your mind on high things but associate with the humble. Do not be wise in your own opinion. (Rom. 12:16, NKJ). The mind is essential as the scripture put forth, and with having the mind of Christ or being in likeness, the leadership of a Christian should also be reflective of his word.

The first family is considered to be role models for the body of believers with the perception of being morally ethical, having Godly values as Juergensen (2000) postulated that "the emphasis on the Word of God in a pastor's family provides a solid training ground where children learn what 
constitutes good character from the perspective of scripture" (p. 106). Therefore, the personal life of the first family is assumed to be immaculate and wholesome.

Although there may be joyous occasions and an appearance of togetherness, there is also struggle and heartbreak. "Some believe that clergy families are different from other families that they live in fishbowl or glass houses" (Juergensen, 2000). As put forward by Friedman (1985):

Problems identified by Friedman that clergy families experience along with all other families are those relating to closeness and distance, the capacity for flexible separation, the ability to maintain self in the context of intimacy, the binding quality of others' expectations, the persistence of misunderstanding, dissatisfaction and resentment in human experience, or the displacement and projection of unresolved issues from one relationship to another, much less from one generation to another. (p. 278)

With understanding Friedman's views, the families are experiencing the same as any other family; however, the difference of those experiences is the intensity of being perfect from those on the outside (external) with the lens. Therefore, the Pastor's leadership is being judged thereby what the family does or does not do.

Pichaske (2017) has proclaimed that an outsider might imagine that the Pastor's home represents an ideal environment for children or a child experience to experience and realize the Christian faith (p. 3). Of course, there is a difference in how the leadership of the Pastor leads the congregants from leading within the home as Pichaske (2017) expressed that his pastoring experience through the lens of his son was "you are not a good pastor at all: you just look like it when you are at church" (p.4). In clergy families, the Pastor's work and his family life can get so intertwined so that everything the family does identifies with the congregation and, in actuality, turns into an augmentation of the congregation; this can be seen in birthday celebrations and missing activities that family members may deem necessary (Juergensen, 2000, p. 58). Possibly by assumption, the way leadership leads in church and leads the family differs because of or is reflected through passed down interactions with other clergy cohorts. As an author put forward, in more traditional settings in America, the understanding of scripture guides the family dynamic of how the home's roles are displayed. For instance, the implication of women being nurturers and sharing the gospel is within the Bible's confines or boundaries and the creation of order explained by (Patterson, 2006, p. 5). The perspective of (Patterson 2006) teachings is reflected with Adam and Eve's fall from grace and Eve's "desires will be unto her husband, and he will have rule over you" (Genesis 3, King James Version). Also, the scripture gives the understanding of order "But I want you to understand that Christ is the head of every man, and the man is the head of a woman, and God is the head of Christ" (1 Corinthians 11:3, NASB) and Ephesians 5: 23 "for the husband is the head of the wife, as Christ also is the head of the church, He himself being the Savior of the body" (Ephesians 5:23, NASB). Therefore, scripture is the fundamental and primary navigation of believers in how leadership should function and how the roles within the leadership homes are determined.

\subsubsection{Christian Leadership}

Moreover, as we look at leadership from the scope of being a Christian Leader, we can see that there has been and there is a movement of transitioning from an understanding of Kessler and Kretzschamar (2015) that "a leader is a person whom other persons follow, and therefore: A Christian leader is a person who follows Christ and whom other persons follow (para 11). Moreover, Niewold (2008) put forward that there are two models that must work well 
together in order for Christian leadership to materialized and make sense, which is divination and humanization.

In other words, there must be a divine presence, and humanistic presence as fleming (2007) expressed that divination is that of inquiring from God in a direct manner as a prophetic inquiry instead of making a request to God. Also, to mention that the nature of a Christian leader should exude a theology of ethics, which are love, modesty, self-development, motivation, correction, integrity, and a follower of God's will" as put forward by (Grunlan, 2018). Knowing the bases of Christian Leadership and taking note of the behavior and the outcome of being a Christian Leader, some leaders are Christians in leadership but are reckless. The migration from the spiritual formation of "what would Jesus do or be like Jesus" is seemingly debunked or removed from men's consciousness more and more.

Furthering this understanding of reckless leadership, the adaption or process of this reckless behavior of the leadership, of course, is seen in many forms and ways. With that being said, looking at the Catholic Church and the non-Catholics as it relates to leadership, there were a substantial amount of misconducts and abuse that appeared to be tolerable (Plante, 2019); in the sense of change, the individuals would be transferred to a different diocese in which more disgraceful acts would occur. How do we as Christians adapt to such things that are morally wrong in society, with the Bible being the rules of engagement? As put forward by Enroth (1992), "spiritual abuse can take place in the context of doctrinally sound, Bible-preaching, fundamentalist, conservative Christianity. All that is needed for abuse is a pastor accountable to no one and therefore beyond confrontation" (p. 189).

\subsubsection{Adaption Leadership}

Looking at adaptive leadership is "one indicator, which a leader uses a variety of different behaviors. However, to be adaptive, the selected behaviors must be relevant for the situations in which they are used" (Yukl \& Mahsud, 2010, p. 82). With a leader having to adapt, they would more than likely adapt to whatever situation derive or whatever is at hand at that moment. For instance, when Jesus saw that the people were hungry while he was teaching, he asked the disciple to see what anyone had to eat in that moment of being a Master (Rabbi) to his disciples, he became the chef or the caterer or the event planner. In ministry, there is a need for many changes significantly during the pandemic of the COVID-19. Church leaders have to redistribute their attention to a more virtual dynamic other than the brick and mortar teaching method and preaching the gospel. The same leadership of adaptive leadership is found in the homes where parents have to adapt along with children.

Perhaps this is more noted with Marital conflict, broadly referred to as marital discord, which tends to refer to the conflict, disharmony, or lack of parental agreement between married parents of children (Reid \& Crisafulli, 1990). Marital conflict can range from verbal to physical abuse and is generally associated with poorer health outcomes for the couples involved (Shrout et al., 2019). The American researchers Straus, Gelles, and Steinmetz (1980) found in their national survey that women's physical abuse was commonly reported in rural regions as in urban centers. One American study found rural people more so than others consider themselves as 'very' or 'fairly' religious and believe that religion has the answer to "all or most of most of today's problems" (anonymous, 1978). In other words, because the pandemic roles of leadership in the homes are possibly overlapping, and the adaptive measures are either becoming successful or not. However, these adaptive measures are committed to memory and become a pattern that one lives. So, with understanding adaptive leadership and Christian leadership, to that point, reckless leadership is found in government, educational institutions, and in homes, but one would never fathom that it would occur in or in the homes of those that preach the gospel. Whether or not this is learned behavior remains 
to be revealed; however, in order for something to be adaptive, there must be a commitment to memory. Understanding memory briefly, there are mental models Jones, Ross, Lynam, Perez, and Leitch (2011) postulated that "cognitive representation of an external reality that is used to anticipate events, reason, and form an explanation" (p. 46). God's word is the primary source and reality, which reflects the mental model of Christian leadership. Also, Johnson-Laird (1983) asserted that "a mental model is a reasoning mechanism that exists in a person's working memory."

\section{Methodology}

The research will be conducted by doing the qualitative method in which the text, image, and data analysis will draw from different designs (Creswell \& Creswell, 2018). The qualitative study for data collection will be those Pastors, wives, and children in the ministry of small churches in rural areas to keep the demographics brief and straightforward. The purpose of the study is to reveal leadership that affects the first family, considering that the targeted churches have been in existence for a while. The research method to understanding an injudicious leadership will convene with a qualitative method. The qualitative design will look at two people (Creswell \& Creswell, 2018). The two individuals will reflect (stories) of their experiences, revealing being reckless and seeing how it affects the first family. The data collection will be that of a narrative approach. A narrative "impart meaning to experiences by integrating them into a temporal and coherent whole with a specific plot structure" (OiliHelena, 2005). Also, Harré (1983) put forward that "the narrative is embodying those with moral orders of good, right and of value." Therefore, telling a story from two individuals will give a synopsis to solidify the study and use field notes to describe the individual embodied behavior and activities. After looking over the information, the findings will determine whether there are similarities or differences. Of the two narratives, the researcher will also give their reflection on the topic because of their experiences. After looking at what the leaders contribute as watching their activities and behavior and listening to their story will give a better understanding of the adaptive behavior and memory that contributes to reckless leadership that affects the first family.

\section{Discussion}

The data collection's focal point is to gather all documents such as the field notes and stories. Also, to establish a theory or give voice to a new finding by analyzing and interpreting what was found to show trustworthiness and validity. With this particular study, the stories are serving as the premise for gathering information to move the study further to understand the adaption and memory and effects of the first family. There were several first families to consider for this research, but because this study is personal, the narrative will come from close to home. With the time for this particular study to occur, there needs to be in-depth research to make this reliable and validated. There are a couple of recommendations to move this study forward. Firstly, a phenomenology approach is well suited for this study. The study will give 3 to 10 participants a solid understanding of effects, which will allow the data collection to be observation and interviews, taking notes paying attention to behaviors and activities during a Sunday service, and service off schedule when the Pastor is not the speaker. Two or three parishioners will suffice for face-to-face or phone interviews, which will be open-ended questions. Patton (2015) made known that using multiple different data collection methods in a study has a better chance of validity because there are several views or ways to view the collection of information (p. 255). This study will also allow saturation when a conclusion can be met where there is no new information. In order to fulfill the 
guidelines of ascertaining trustworthiness, there need to be four to five participants for saturation (Padgett, 2017).

\subsection{Participate in story 1}

Good evening; Let me give you a little bit of my history my story. I got married at 19, and I married a preacher. Moreover, we left home, and we moved to Atlanta, Georgia. Furthermore, it is my first time away from my family, and I realized that my husband was different or showed some differences in church and outside of the family. He was often seen as soft-spoken to many people but yet abusive. I had my first encounter with being hit with a lamp and had so many questions that I could not believe. The questions like, Oh my God, what is going on here, and what is wrong with me. Is it me, and what did I do? We moved out of his mom's house into our little apartment.

Moreover, the abuse continued, and I frequently would ask them what is going on, and he was offered a church, and we left New York altogether. We moved to the south, and we bought a home and had three kids, and as my kids grew, the abuse never stopped.

As the first lady in a church, I would take the abuse, and, you know, go to the church and smile, and I was musician, and I would play, and no one ever knew the hurt or oppression that I was going through. I stayed in the situation for 13 years. Moreover, I began to ask myself why am I doing this, you know, and in the back of my mind, I remembered. I grew up in a church that said you only could be married to one man and be submissive. The divorce was not an option.

Furthermore, because I wanted my kids to have a father and a life, I stayed those 13 years. It did not get any easier. It got worse because my husband started cheating on me. Moreover, I caught him a couple of times, and we had it out. And, I would go to church and smile, greet the people as usual. And inside hurting. He would smile and grin at all the members and would not, per se, recognize me. Also, I am sitting there playing and singing. It was just our hurtful feeling as years passed, of course.

I said to myself, well, God did not want me to do it like this, you know, and I will not do this anymore. He was abusive to my kids. Moreover, that was my last straw. Thus, I said, okay, from this point on, I am leaving. I have had enough. After leaving, and I moved back home. You know I tried to try to get back with him. I then realized that I was being used as a prostitute because he would not take care of the kids and me. However, he was preaching to me at church.

Furthermore, you know, he did his religious duties, I guess. Meanwhile, here I was, I was done, just wholly done, and I would not consider marrying another preacher. However, everybody is not the same. Nevertheless, it is a hurtful situation. I pray that a lot of the young first family. Do not stay in it as long or put up with that kind of behavior from anybody.

\subsection{Participant in story 2}

There are two different dynamics of leadership from being in public to being private. Moreover, being in public would always give the appearance of joy, love, patience, and peace. However, on the other side of the coin, there would be ridicule, criticism, no peace, and no patience. I am a pastor of a small group of people, and my husband is also a pastor. We have three children in the home where two are off to college. I am the daughter of a Pastor, which makes my mother the first lady growing up; the dynamic of church life was viewed, and there was a saying that what goes on in the house stay in the house. The privacy of the family also embarked upon dysfunction. As I attempt to tell the story of reckless leadership, I can recall the difference early in which the adaptation was carried over into my 
adulthood. The isolation and the lack of fellowship with the saints rendered a sense of uncertainty of people's motives. Therefore, the adaptive behavior of being in reserve, shy, cautious carried over because of the behaviors caught within the home. My father's leadership was different in the home; there was no patience and no encouragement, and the liberty to have fun was not acceptable.

I find myself repeating what was taught and caught with raising my children, although not knowing whether it is beneficial. Firstly, I had no intention of marrying a preacher, let alone a pastor, and upon doing so, the behavioral dynamics of the leadership was different in the church from interacting with the family. I rendered the same words that were given to me "what goes on in the house stays in the house." The rationale for that was that the first family has an image to uphold as an example for all other families. There is a sense of authority in the church that carries over to the home that everyone walks on eggshells. The communication and interaction were not the same as it was within the church. For instance, I would get more accolades for my beauty when at church than at home; however, there was more criticism and negativity in the home. People would look at us and call us a power couple, and the home would be different.

The adaptive mechanism began with me overlooking the difference of treatment of others in the ministry versus the first family. The neglect of communication and expressing genuine love towards us show in the children that as they were getting older, they recall the empty seats of not showing up to activities because of the church and embracing other people's kids with hugs and expressions of happiness. The missing elements of a wholesome biblical family are lost, and the behavior becomes a memory after accepting the repeat behavior. One of the reasons I condone the behavior or covered the behavior is that I understood not going against the leadership or God's chosen vessel and not displaying any negative feedback on the individual and the ministry. Most of the time, you do more praying to make sure you are walking according to the word, are qualified, and question your motives. However, the deceit and the double life becomes overwhelming because the children are looking at the double standard, and I am looking in the mirror of the double standard.

\section{Conclusion}

Therefore, reckless leadership is a learned behavior because somethings are taught, and some things are caught. There was a close look at the first family dynamic and how they are looked upon through the lens of a worldview. Understanding Christian leadership was explored to develop a consensus of what the Christian leader should display or behave. Also, adaptive leadership was rendered to explain how situations cause adaptation. There was a mental model that would suggest how memory becomes one's reality. The two participants were also allowed to render their story as a narrative approach to understanding the effects of the first family with reckless leadership and how they adapted to the behavior and allowed the memory to move forward. The recommendation for this study is to make a more in-depth approach of a phenomenology design to gather more information and more saturation of individuals to make these findings valid and reliable.

\section{References}

Beck, K., and Ralph, J. (1994). Patterns Generate Architectures. Proceedings of European Conference of Object-Oriented Programming. Bologna, Italy, pp. 139-149.

Bass, B. M. (1990). From transactional to transformational leadership: Learning to share the vision. Organizational Dynamics. Winter, 19-31. 
Burns, W. A. JR. (2017). A descriptive literature review of harmful leadership styles: Definitions, commonalities, measurements, negative impacts, and ways to improve these harmful leadership styles. Creighton Journal of Interdisciplinary Leadership, 3(1), 33-52.

Enroth, A. (1992). Churches that abuse. Grand Rapids, MI: Zondervan.

Fleming, E. E. (2007). She went to inquire of the Lord: Independent divination in Genesis 25:22. Union Seminary Quarterly Review, 60(3-4), 1-10.

Friedman, E. H. (1985). Generation to Generation: Family Process in Church and Synagogue. New York: The Guilford Press.

Grunlan, S. (2018). What is Christian leadership? 8 principles. Ministry Magazine. Available from https://online.campbellsville.edu.

Harré, R. (1983). Personal being. Oxford: Basil Blackwell.

Johnson-Laird, P. N. (1983). Mental models. Cambridge, UK: Cambridge University Press

Jones, N. A., Ross, H., Lynam, T., Perez, P., \& Leitch. A. (2011). Mental models: An interdisciplinary synthesis of theory and methods. Ecology and Society 16(1): 46. Available from http://www.ecologyandsociety.org/vol16/iss1/art46/

Juergensen, S. (2000). Growing Up as a Pastor's Child-The Pressures and Positives of Living in a Clergy Family System. Doctor of Ministry Major Applied Project. 82. Retrieved https://scholar.csl.edu/dmin/82

Kessler, V., \& Kretzschmar, L. (2015). Christian leadership as a trans-disciplinary field of study. Verbum Et Ecclesia, 36(1), 1-8. Retrieved from http://eres.regent.edu:2048/login?url=https://search-proquestcom.ezproxy.regent.edu/docview/1737513629?accountid=13479

Niewold, Jack. (, 2007). Beyond Servant Leadership. Journal of Biblical Perspectives in Leadership. 1 (2), 118-134.

Oili-Helena Ylijoki. (, 2005). Academic nostalgia: A narrative approach to academic work. Human Relations, 58(5), 555-576. Retrieved from http://eres.regent.edu:2048/login?url=https://www-proquestcom.ezproxy.regent.edu/scholarly-journals/academic-nostalgia-narrative-approachwork/docview/231524461/se-2?accountid=13479.

Padgett, D. (2017). Qualitative methods in social work research. Thousand Oaks, California: SAGE Publication.

Patton, M. Q. (2015). Qualitative research \& evaluation methods: Integrating theory and practice. Thousand Oak, California: SAGE Publication.

Reid, W. J., \& Crisafulli, A. (1990). Marital discord and child behavior problems: A metaanalysis. Journal of Abnormal Child Psychology, 18(1), 105-117.

Straus, M., Gelles, R. S., \& STEINMET, L. S. (1980). Behind closed doors: Violence in the American Family.

Yulk, G \& Mahsud, R. (2010). Why flexible and adaptive leadership is essential. Consulting Psychology Journal: Practice and Research, 62(2), 81-93. 